\title{
E-Commerce Adoption Model for Traditional Retailers in Developing Countries
}

\author{
Husam Yaseen ${ }^{1}$, Moh'd Alhusban ${ }^{2}$, Kate Dingley ${ }^{1}$, Amal Alhosban ${ }^{3}$ \\ ${ }^{1}$ University of Portsmouth, $U K$ \\ ${ }^{2}$ Southampton Solent University, UK \\ ${ }^{3}$ University of Michigan Flint, USA
}

\begin{abstract}
It is generally believed that B2C e-commerce will help businesses in developing countries to reduce cost and to improve their access to global market. Yet, developing countries are still some way from success in their adoption of B2C e-commerce. This paper attempts to provide insights into the salient e-commerce adoption issues by focusing on traditional Jordanian retailers. A focus group was conducted with traditional retailers from various businesses types in Jordan. Five themes have emerged in the context of this paper: the common understanding of e-commerce concepts, barriers, and drivers from retailers' view, the readiness and willingness towards e-commerce adoption, and potential solutions where e-commerce can take off and encourage traditional retailers. The study revealed that traditional retailers in Jordan are fully aware of e-commerce benefits and they showed a willingness to adopt e-commerce. However, the participants were agreed about the lack of awareness and knowledge of what is needed to be done. Also, there were many concerns about the absence of government support. Based on the findings, the study developed a conceptual model which attempts to illustrate the essential requirements to help businesses successfully adopt ecommerce.
\end{abstract}

\section{Introduction}

Electronic commerce (e-commerce) has become an increasingly important initiative among businesses. Businesses adopt e-commerce for various reasons and perceived benefits. Some of these benefits include better sales, better integration of suppliers, more marketing channels, lower transaction costs, better customer communication, and market expansion [1]. In addition, e-commerce has not only provided value for businesses but has also increased the rate of economic growth. In fact, it has impacted efficiency, effectiveness, productivity and quality in terms of expense reduction, increased revenue, and return on investment (ROI).

Businesses in most countries are undertaking ambitious steps to transform their businesses and are moving toward adopting e-commerce. Although the diffusion of Information Communications Technology (ICT) into businesses is essential for the achievement of productivity, growth, and the efficient functioning of the information society, most businesses in developing countries have not benefitted from ICT [50]. The factors affecting ecommerce adoption decisions have been well studied, but few studies have investigated the adoption of e-commerce among businesses in developing countries [2]. Consequently, there is still doubt about how Business -to-Customer (B2C) ecommerce will lead firms in developing countries to new trading opportunities [3]. Thus, understanding B2C e-commerce adoption has become an important issue. Despite Jordan investing heavily in developing its ICT sector, seeking to enhance the performance of its private 4 , e-commerce adoption among businesses is still lagging behind. This study was conducted to address the gap in the e-commerce adoption literature by exploring this topic in developing countries, using Jordan as a case study. In particular, this paper attempts to provide insights into the salient e-commerce adoption issues by focusing on traditional Jordanian retailers.

Unlike other developing countries in the Middle East, Jordan has the largest number of online startups and entrepreneurs in the Middle East region [5]. Additionally, Jordan shows a greater readiness for ecommerce compared to other developing countries. The technological infrastructure in Jordan is robust [6]. Despite the substantial strain on infrastructure, Jordan in the past few years has witnessed socioeconomic issues resulting from the new Arabic spring. As a result, many changes have been made to cope with this pressure. It is, therefore, important to assess how these recent changes affect Jordanian businesses regarding e-commerce adoption since it is believed that socioeconomic factors play a crucial role in ICT development. Jordan has been chosen in this study because it presents a unique and interesting case as a developing country.

The adoption of e-commerce by traditional businesses generally in Jordan is still relatively new [7]. Without a doubt, limited studies have 
investigated the emerging e-commerce in Jordan. Consequently, it is essential to gain an in-depth understanding of e-commerce as a concept as well as the barriers and drivers from non-adopters' perspectives. Therefore, this study aimed at answering questions related to e-commerce adoption in Jordan. Five themes emerged: a common understanding of the e-commerce concept, barriers and drivers from retailers' point of view, the readiness and willingness for e-commerce adoption, and potential solutions to boost e-commerce and encourage traditional retailers. The study findings have contributed to the academic debate by underlining the challenges and opportunities for traditional businesses and shed light on whether it is possible to adopt e-commerce.

\section{Literature Review}

\subsection{E-commerce in Jordan}

E-commerce is a term used to describe the use of electronic communication networks and services, which enables businesses to work together with their customers. Usually, it involves collaboration between businesses and customers facilitating the supply of goods and services, customer support, and trading [4]. E-commerce is defined in a variety of ways, all of which share similar key premises. For example, the ESCWA definition describes ecommerce as 'conducting business transactions online' [4]. This definition identifies that ecommerce concerns the sale of both products and services. For the purpose of this paper, e-commerce is defined as 'transactions associated with trading of goods or services, or their development over a telecommunications network' [8].

E-commerce adoption in Jordan is quite low with the majority of the population shunning the use of modern ICT in their transactions and banking. Jordan's institutions and government are well placed to adopt e-commerce, but it seems psychological barriers have been a major hindrance to its adoption. Businesses, academics, and public servants do not trust electronic transactions and have held on to traditional old transaction methods. In spite of this, Jordan is third behind Bahrain and the United Arab Emirates in terms of its readiness for e-commerce in the Middle East region [4]. A national e-commerce strategy developed by Jordan's Ministry of Information and Telecommunications Technology sought to overcome the obstacles in Jordan's adoption of e-commerce. In a report containing the strategy, key obstacles were identified, and methods were devised to address issues that were an impediment to e-commerce adoption in Jordan. The Five key obstacles identified were 1 - lack of reliable electronic payment system. 2 - lack of laws which support e-commerce processes and which protect its users. 3 - lack of awareness amongst stakeholders regarding e-commerce. 4 - affordability - high cost of broadband access and PCs, and 5 - unfavourable licensing and tax conditions, which deter ecommerce entrepreneurs [4].

\subsection{E-commerce Readiness in Jordan}

The previous assessment of the state of ecommerce readiness in Jordan has revealed that the country scores adequately high in terms of technical preparedness and professional preparedness. It, however, lacks the social impetus to match its ecommerce performance with its technical infrastructure. According to Shannak and Al-Debei [8], Jordan exhibits adequate preparedness for efficient e-commerce technologies. In this sense, the infrastructure to facilitate e-commerce, including telecommunication, government, and institutional support, the readiness of appropriate organisations and the Jordanian community culture is generally good [8]. The country's level of cultural preparedness is however not good enough for Jordan to reach the e-commerce readiness stage. The level of e-commerce adoption among Jordan's corporate sector is also very low with less than 20 companies applying e-commerce in their business [8]. The researchers envision two possible scenarios that could result in adequate spreading and implementation of e-commerce in the Jordanian corporate sector. The first scenario is where the private sector takes the initiative to adopt ecommerce and then the government will follow suit. The second is where the government adopts ecommerce in its offices, including public service, thereby providing an example for the private sector to follow. According to the researchers, the second scenario is more likely to occur than the first.

\subsection{E-commerce Adoption Initiatives}

While some e-commerce initiatives are managed successfully, many businesses are faced with various challenges that originate from a combination of internal and external factors. Therefore, it is important to understand those factors that affect ecommerce adoption. Prior literature has identified these factors such as government support, cognitive issues, legal issues, technological issues, and much more. The factors outlined in the following subsections present a common pattern that offers useful insight for businesses still experiencing challenges with e-commerce adoption.

2.3.1. Government Initiatives. Government initiatives are important in the adoption of ecommerce especially in developing countries [9]; [10]; [11]; [12]; [13]; [14]. They can encourage the private sector to adopt e-commerce by providing 
supportive infrastructure, legal and regulatory frameworks. In developing countries, the government is usually responsible for technology development, and it can influence e-commerce implementation decisions. Therefore, its level of support can encourage e-commerce adoption [15]; [46]. However, different firms may perceive the level of governmental readiness differently. This might influence their decisions to adopt e-commerce. Many studies have explored the level of government support towards e-commerce adoption and have found that adopter firms perceived higher government support than non-adopter firms [16]; [17]; [10]; [18]; [15]; [19]; [20]; [21]. In Italy, Scupola [22], found that the government plays an important role as an external factor affecting ecommerce adoption. Furthermore, in another study conducted in Australia and Denmark, Scupola [47] found that the role of government incentives was the greatest for Australian business, but this was not the case for the Danish businesses. In Singapore, however, the government support level was high enough to lead the country in e-commerce adoption, not only in their initiative towards e-commerce infrastructure but also in developing a strategic plan to increase the level of awareness among society [10]. On the other hand, lack of governmental support was a significant barrier to e-commerce adoption in Oman [23], and Saudi Arabia [24]. In the past, the Jordanian government has proposed many initiatives to provide guidance and support for the private sector with regard to e-commerce system implementation [25]. However, in the last few years, the government has focused on implementing and developing the e-government programme. Consequently, the government has not been focused on the development of e-commerce in the country. This can be explained by the sudden shift in the amount of research conducted in the field of egovernment compared with e-commerce. According to Al-Weshah and Al-Zubi [7], the Jordanian government should plan strategies to achieve and raise national awareness of the Internet and ecommerce by increasing investment in the ICT infrastructure.

2.3.2. Awareness. Awareness describes the perception of e- commerce elements in the environment, comprehension of their meaning, understanding e- commerce technologies, business models, requirements, benefits and threats and projection of the future trends of e-commerce and its impact [15]. Rogers [26], argued that awareness of an innovation and its benefits is an important initial stage that may affect the decision to adopt or reject the innovation. As soon as businesses become aware of the potential of e-commerce and make an initial adoption decision, they continue to adopt beyond the entry- level. According to Molla and Licker [15], lack of e- commerce awareness is a factor taken for granted in developed countries. As a result, many businesses have not considered exploiting the potential of e- commerce to improve their business operations [25]. Lack of e-commerce awareness among businesses was found in Saudi Arabia [16]; [27]; [28]; [29] and India [30]; [31]. Furthermore, Al Nagi and Hamdan [32] pointed out that Jordan is still facing some obstacles. One such obstacle is the lack of e- commerce awareness that prevents many companies from doing business online. Similarity, [8] found that the main reason underlying the very small number of e-commerce applications by Jordanian companies is a lack of awareness.

Moreover, Yaseen et al. [33] conducted a study by analysing e-commerce related articles in the Jordanian English newspaper (The Jordan Times) for the last ten years; they found the lack of awareness was one of the most crucial challenges that ecommerce faces in Jordan. They pointed out that awareness is the first step towards e- commerce adoption.

\section{Methodology}

\subsection{Research Approach}

This study seeks to investigate the current practice, understanding, and common issues regarding e-commerce through the lens of traditional retailers in Jordan. Thus, a focus group was conducted with owners of traditional retailers, which are the potential businesses that could act as a leading model. A focus group is usually conducted with a specific purpose to address a knowledge gap that the focus group is supposed to fulfil. A focus group is an appropriate method to gather knowledge from various individuals.

Each individual in the study has knowledge on a specific issue and when this information comes together, is shared and discussed, the results should highlight some potential outcomes. The researcher guided the group by posing open-ended questions and questions oriented towards e-commerce practices. The group comprised owners of traditional businesses in different parts of Jordan, where the transformation is likely to begin; as mentioned in the theoretical background, traditional retailers are potentially a target for the initial adoption of ecommerce. The focus group involved twelve participants from various retail sectors (mobile and technology shop, clothing shop, grocery shop, food industry, bookstore, and maintenance and construction). Table 1 identifies the participants and their businesses. The discussion took place on 26th of July 2016; each participant was asked about their perceptions, opinions, beliefs, and attitudes towards e-commerce adoption in Jordan. 
Table 1. Focus Group Participants

\begin{tabular}{|c|c|c|c|}
\hline \multirow{14}{*}{$\begin{array}{l}\text { Focus } \\
\text { group }\end{array}$} & Respondent & $\begin{array}{l}\text { Years of } \\
\text { Business }\end{array}$ & Role \\
\hline & $\begin{array}{l}\text { Mobile } \\
\text { Technology }\end{array}$ & 6 & Owner \\
\hline & $\begin{array}{l}\text { Mobile } \\
\text { Technology }\end{array}$ & 3 & Owner \\
\hline & $\begin{array}{l}\text { Mobile } \\
\text { Technology }\end{array}$ & 5 & Owner \\
\hline & Food industry & 8 & Owner \\
\hline & Food industry & 3 & Owner \\
\hline & Bookstore & 4 & Owner \\
\hline & Bookstore & 10 & Owner \\
\hline & Groceries shop & 2 & Owner \\
\hline & Groceries shop & 1 & Owner \\
\hline & Clothing shop & 4 & Owner \\
\hline & Clothing shop & 2 & Owner \\
\hline & $\begin{array}{l}\text { Maintenance } \\
\text { construction }\end{array}$ & 12 & Owner \\
\hline & $\begin{array}{l}\text { Maintenance } \\
\text { construction }\end{array}$ & 5 & Owner \\
\hline
\end{tabular}

\subsection{Formulating the Questions}

Because a focus group lasts roughly one or two hours, time will only allow for four to seven questions. The focus group began with introductory and ice-breaker questions and then delved into more focused questions on the core issue. The introduction lasted roughly 10 minutes where the traditional retailers were asked how they conduct their businesses. The e-commerce concept was explained to the group, and accordingly, questions were formulated based on the perceived benefits and barriers of adoption. The researcher explained the implementation scenario (e-commerce adoption) to the group.

Questions were asked to assess the local traditional retailers' readiness to adopt e-commerce. As depicted in Table 2, the researcher began with the participants' understanding of the online business concept. This opening question, where participants became familiar and warmed up, shed some light on how e-commerce activities are performed. Asking about the definition of online businesses also helped in identifying any possible ambiguity about this topic which could impact achieving a common goal or implementation. The second question directly asked about the barriers that hinder e-commerce adoption; in line with previous research, this study assumes that technology infrastructure is not the main barrier to partial or initial e-commerce adoption. Therefore, this question helped identify some of the existing issues in terms of governmental and stakeholder's collaboration and support.

The third question was open-ended and aimed at identifying the drivers and motivations to adopt ecommerce among the different retailers. This helped to measure the potential collaboration between retailers and other stakeholders. The fourth question explored the retailers' views on their readiness to adopt as well as identify successful implementation factors. This fourth question sought to discern the essential steps of adoption as perceived by traditional businesses and further expand on the drivers of ecommerce adoption. The fifth question asked about the main requirements that are potentially needed to be ready for adoption, as well as what it would take to make being an online retailer possible.

Table 2. Focus group questions

\begin{tabular}{|c|c|}
\hline Participants & Questions \\
\hline \multirow{4}{*}{$\begin{array}{c}\text { Traditional } \\
\text { retailers in } \\
\text { Jordan }\end{array}$} & The definition of electronic commerce \\
\cline { 2 - 2 } & Barriers to e-commerce adoption \\
\cline { 2 - 2 } & Drivers of successful e-commerce \\
\cline { 2 - 2 } & Readiness for implementation \\
\cline { 2 - 2 } & What are the requirements? \\
\hline
\end{tabular}

\subsection{Focus Group Analysis}

This study adopted the collaborative social research approach where the researcher and a group work together to share their knowledge and ideas about a specific area in need of improvement. The analysis of data gathered in such a collaborative approach is accomplished with the participants, who are potential online business retailers. In this study,audio recorded conversations were produced (a total of 2:42 hours). Analysing the focus group involved various steps. Firstly, key themes and areas of agreement or disagreement were identified as well as observing useful quotations which answer the objectives of this research.

The recordings were transcribed and typed. This process was achieved by listening to the recordings, and transcript in Arabic and then translating the produced transcript into English. While this process took time, the results and outcomes were confirmed in both languages, helping the researcher to capture some of the expressions and colloquial language used by traditional retailers in the context of businesses. In addition, the double review process has significantly contributed to identifying themes and patterns in the focus group discussion. In total, the recorded conversations resulted in 16 pages of transcription in both Arabic and English. After the transcription and translation, data could be more easily visually analysed where commonalities and patterns were identified and developed into codes as depicted in the following Table. 
Table 3. Focus group codes and patterns

\begin{tabular}{|l|l|l|l|}
\hline Definitions & Drivers & Barriers & Requirements \\
\hline $\begin{array}{l}\text { Selling products } \\
\text { around the world }\end{array}$ & $\begin{array}{l}\text { Global } \\
\text { reach }\end{array}$ & $\begin{array}{l}\text { Tax and } \\
\text { customs }\end{array}$ & $\begin{array}{l}\text { Joint- } \\
\text { collaboration }\end{array}$ \\
\hline $\begin{array}{l}\text { Transaction } \\
\text { between online } \\
\text { retailers }\end{array}$ & $\begin{array}{l}\text { Improve } \\
\text { communications }\end{array}$ & $\begin{array}{l}\text { Protection } \\
\text { law }\end{array}$ & $\begin{array}{l}\text { Increased } \\
\text { awareness }\end{array}$ \\
\hline $\begin{array}{l}\text { Market } \\
\text { expansion }\end{array}$ & $\begin{array}{l}\text { New products } \\
\text { and services }\end{array}$ & $\begin{array}{l}\text { Government } \\
\text { support }\end{array}$ & $\begin{array}{l}\text { Government } \\
\text { support }\end{array}$ \\
\hline $\begin{array}{l}\text { Moving from } \\
\text { traditional } \\
\text { environment to } \\
\text { digital }\end{array}$ & $\begin{array}{l}\text { Increase } \\
\text { brand }\end{array}$ & $\begin{array}{l}\text { Continuous } \\
\text { changing } \\
\text { rules and and } \\
\text { policies }\end{array}$ & Protection \\
\hline $\begin{array}{l}\text { Using the Internet } \\
\text { to shop }\end{array}$ & $\begin{array}{l}\text { Collaboration } \\
\text { between } \\
\text { stakeholders and } \\
\text { government }\end{array}$ & $\begin{array}{l}\text { Lack of } \\
\text { awareness }\end{array}$ & Decreased prices \\
\hline
\end{tabular}

Question 1: The Definition of Electronic Commerce. The answers in the following Table were provided by the participants in the focus group. Each participant answered the question based on his knowledge and experience. The answers presented in Table 4a were chosen after a review of the transcripts in both Arabic and English. Thus, common patterns started to appear in the transcript, and a list of themes began to emerge; these themes were collected and presented in the previous table (see Table 3). The identified themes were highlighted and then later moved onto a separate sheet, where the most frequent answers were collated within one category.

Table 4a. Question 1: E-Commerce Definitions

\begin{tabular}{|c|c|l|}
\hline $\begin{array}{l}\text { Question } \\
\text { No. }\end{array}$ & $\begin{array}{l}\text { Answer } \\
\text { No. }\end{array}$ & \multicolumn{1}{|c|}{ Answer } \\
\hline 1 & 1 & $\begin{array}{l}\text { Online shop that sells } \\
\text { products to customers } \\
\text { around the world. }\end{array}$ \\
\hline 1 & 2 & $\begin{array}{l}\text { A two-way transaction } \\
\text { conducted between retailers } \\
\text { over the internet. }\end{array}$ \\
\hline 1 & 3 & $\begin{array}{l}\text { An expansion of a current } \\
\text { business to a global reach. }\end{array}$ \\
\hline 1 & 4 & $\begin{array}{l}\text { A service which allows } \\
\text { customers and retailers to } \\
\text { sell and purchase using a } \\
\text { web browser. }\end{array}$ \\
\hline 1 & 5 & $\begin{array}{l}\text { The transformation from } \\
\text { physical market to digital } \\
\text { market. }\end{array}$ \\
\hline
\end{tabular}

The next step in the content analysis was to categories the participants' answers according to the emerging themes, to help identify relationships, differences, and commonalities. Therefore, a matrix table helps identify commonalities across the answers of the participants. As a result, Table $4 \mathrm{~b}$ was generated, illustrating the variation in the answers given, depending on the participants' type of business. These differences were apparent in $\mathrm{M} \& \mathrm{C}$ (maintenance \& construction) and G (grocery shop) due to the nature of their business; these participants had the fewest responses to this first question. Both $\mathrm{M} \& \mathrm{C}$ and $\mathrm{G}$ viewed e-commerce as an online platform that can be used to sell and purchase products globally, illustrating that their answers were based on the definition itself. They also both said ecommerce involves selling products around the world, indicating the nature of their business, which can only be achieved within a specific demographic location. This also applied to the food industry (F). Additionally, participants from the M\&T (mobile \& technology) provided all of the answers in Table $4 b$, and this is because there are some similar businesses considering e-commerce.

Table 4b. Perceptions of E-Commerce

\begin{tabular}{|c|c|c|c|c|c|c|}
\hline Theme 1 & \multicolumn{6}{|c|}{ Perception of E-Commerce } \\
\hline Q1 & M\&T & $\mathbf{F}$ & $\mathbf{B}$ & $\mathbf{G}$ & $\mathbf{C}$ & M\&C \\
\hline A1 & $\mathrm{x}$ & $\mathrm{x}$ & $\mathrm{x}$ & $\mathrm{x}$ & $\mathrm{x}$ & $\mathrm{x}$ \\
\hline $\mathrm{A} 2$ & $\mathrm{x}$ & & & & & \\
\hline A3 & $\mathrm{X}$ & & $\mathrm{x}$ & & $\mathrm{X}$ & \\
\hline A4 & $\mathrm{x}$ & $\mathrm{x}$ & $\mathrm{x}$ & $\mathrm{x}$ & $\mathrm{x}$ & $\mathrm{x}$ \\
\hline A5 & $\mathrm{X}$ & $\mathrm{x}$ & $\mathrm{x}$ & & $\mathrm{x}$ & \\
\hline
\end{tabular}

The most important finding in this analysis is answer 4 (A4), where all groups stated that ecommerce is a service which allows them to sell products using a web-browser. Despite the various definitions given by participants, a common understanding of e- commerce emerged. Therefore, e-commerce broadly can be perceived as a transformation phase from a traditional to an online environment to sell and purchase products/services all over the world using the Internet.

Question 2: Barriers for E-Commerce Adoption. Question 2 asked about the barriers that hinder ecommerce adoption; as previously mentioned, this research assumes that technology infrastructure is not the main barrier to e-commerce adoption and implementation. The participating retailers have contributed the majority of the answers in this theme. From the number of answers given by different participants, there were more barriers to adoption than drivers, as three businesses participants seemed to hold a very negative view on the level of government support. Participants cited 'Continuous changing government rules, taxes and customs policies' as some of the barriers. As a result, this directed the focus group to discuss the role of government and whether those barriers could be solved by more collaborative work from the private sectors. 
Table 5a. Question 2: Barriers for E-Commerce Adoption

\begin{tabular}{|c|c|l|}
\hline $\begin{array}{l}\text { Question } \\
\text { No. }\end{array}$ & $\begin{array}{l}\text { Answer } \\
\text { No. }\end{array}$ & \multicolumn{1}{|c|}{ Answer } \\
\hline 2 & 1 & $\begin{array}{l}\text { Customer protection law and online } \\
\text { payment methods }\end{array}$ \\
\hline 2 & 2 & Taxing and customs policies \\
\hline 3 & 3 & $\begin{array}{l}\text { Continuous changing government rules } \\
\text { and procedures }\end{array}$ \\
\hline 2 & 4 & Lack of government support \\
\hline 2 & 5 & Lack of awareness and trust \\
\hline
\end{tabular}

Table 5b. Barriers to E-Commerce Adoption

\begin{tabular}{|c|c|c|c|c|c|c|}
\hline Theme2 & \multicolumn{6}{|c|}{ Barriers to E-Commerce Adoption } \\
\hline Q2 & M\&T & F & B & G & C & M\&C \\
\hline A1 & x & x & $\mathrm{x}$ & & $\mathrm{x}$ & \\
\hline A2 & x & & $\mathrm{x}$ & $\mathrm{x}$ & $\mathrm{x}$ & $\mathrm{x}$ \\
\hline A3 & $\mathrm{x}$ & & $\mathrm{x}$ & $\mathrm{x}$ & $\mathrm{x}$ & \\
\hline A4 & $\mathrm{x}$ & $\mathrm{x}$ & $\mathrm{x}$ & $\mathrm{x}$ & $\mathrm{x}$ & $\mathrm{x}$ \\
\hline A5 & $\mathrm{x}$ & $\mathrm{x}$ & $\mathrm{x}$ & $\mathrm{x}$ & $\mathrm{x}$ & $\mathrm{x}$ \\
\hline
\end{tabular}

As seen in Table 5b, participants generally cited similar barriers to adoption. All participants stated lack of awareness of trust, reflecting complex psychological and cultural aspects. Retailers usually hesitate to adopt new technology for many reasons including resistance to change, lack of knowledge about the potential of online businesses, lack of trust in various aspects such as security, privacy, and customers' trust, as well as psycho-behavioural barriers such as awareness [41], [48]. The reason why Jordanian retailers lack initiative in the adoption of e-commerce may stem from inadequate knowledge about e-commerce. From the focus group discussion, most of the retailers do not have a good understanding of this new technology and new business model.

Participant: 'If we decided to adopt e-commerce, how we can start? and how does it work?'

Therefore, the joint collaboration between the government, stakeholders, and retailers is quite essential to increase awareness. This can also be generally delivered in the form of short courses, workshops, seminars, and lectures in order to enhance knowledge and build trust.
Question 3: Drivers of Successful E-Commerce. The next theme presented in Table 6a presents the drivers of successful e-commerce. Some interesting patterns emerged. Firstly, most participants mentioned that e-commerce offers new channels to sell their products/services. This seems to reflect concerns about the type of products and services that are provided by those retailers. Another interesting insight was that all retailers agreed on the need for joint collaboration between stakeholders and the government to create a convenient shopping environment (see Table 6b). This appears to be the prerequisite driver for successful e-commerce transformation and highlights the role of the government in successfully implementing the egovernment programme.

Table 6a. Question 3: Drivers of Successful ECommerce

\begin{tabular}{|c|c|l|}
\hline Question No. & Answer No. & \multicolumn{1}{|c|}{ Answer } \\
\hline 3 & 1 & Expansion and global reach \\
\hline 3 & 2 & $\begin{array}{l}\text { Improve communications between customers and } \\
\text { retailers }\end{array}$ \\
\hline 3 & 3 & $\begin{array}{l}\text { Offer new types of goods and services through new } \\
\text { channels }\end{array}$ \\
\hline 3 & 4 & Increase brand trust and loyalty \\
\hline 3 & 5 & $\begin{array}{l}\text { Collaboration between stakeholders and government to } \\
\text { facilitate a convenient shopping environment }\end{array}$ \\
\hline
\end{tabular}

Table 6b. Drivers of Successful E-Commerce

\begin{tabular}{|c|c|c|c|c|c|c|}
\hline Theme 3 & \multicolumn{5}{|c|}{ Drivers of E-Commerce } \\
\hline Q3 & M\&T & F & B & G & C & M\&C \\
\hline A1 & x & & x & & x & \\
\hline A2 & x & x & & x & & \\
\hline A3 & x & x & & x & x & x \\
\hline A4 & & & & & x & \\
\hline A5 & x & x & x & x & x & x \\
\hline
\end{tabular}

Another interesting observation is answer 4 (A4) where only the clothing shop retailers (C) mentioned increasing brand trust and loyalty as one of the important drivers of e-commerce. This is one of the core elements of online shopping, as trust is perceived to be the most fundamental factor affecting the success or failure of online shopping. Many previous researchers have investigated the relationship between online shopping and trust, and brand loyalty [42], [43], [44], [45]. In sum, the participants emphasised that successful e-commerce 
would include collaborating together to achieve a convenient shopping environment, an integrated online platform, better infrastructure along with suitable policies and regulations. The drivers have been implicitly underlined by using terms such as communication and collaboration, illustrating that retailers seem to be familiar with what is needed for an online transformation. Therefore, the various terms used such as 'help', 'improve', and 'increase' indicate the willingness and readiness of these retailers to be part of this collaboration towards successful e-commerce.

Question 4: Implementation Readiness. This question sought to explore the readiness for ecommerce and the factors necessary for implementation. This will help to develop implementation factors, such as answer 2 (A2) regarding the level of support provided by the government. All retailers agreed that the government is responsible for encouraging implementation, as some of the challenges cannot be addressed without the government's support.

Table 7a. Question 4: Readiness for Implementation

\begin{tabular}{|c|c|l|}
\hline $\begin{array}{l}\text { Question } \\
\text { No. }\end{array}$ & $\begin{array}{l}\text { Answer } \\
\text { No. }\end{array}$ & \multicolumn{1}{|c|}{ Answer } \\
\hline 4 & 1 & $\begin{array}{l}\text { Re-endorsement of online } \\
\text { transaction law and customer } \\
\text { protection law }\end{array}$ \\
\hline 4 & 2 & $\begin{array}{l}\text { Support level provided by } \\
\text { government }\end{array}$ \\
\hline 4 & 3 & Internet prices and accessibility \\
\hline 4 & 4 & $\begin{array}{l}\text { Raising awareness for both } \\
\text { businesses and customers in } \\
\text { various channels }\end{array}$ \\
\hline 4 & 5 & $\begin{array}{l}\text { A first step initiated by the } \\
\text { government or well-known } \\
\text { businesses }\end{array}$ \\
\hline & & \\
\hline
\end{tabular}

Table 7b. Readiness for implementation

\begin{tabular}{|c|c|c|c|c|c|c|}
\hline Theme 4 & \multicolumn{5}{|c|}{ Readiness of Implementation } \\
\hline Q4 & M\&T & F & B & G & C & M\&C \\
\hline A1 & x & & x & & x & \\
\hline A2 & x & x & x & x & x & x \\
\hline A3 & x & & & x & & \\
\hline A4 & x & x & x & x & x & x \\
\hline A5 & x & x & x & x & x & x \\
\hline
\end{tabular}

As previously identified in the drivers of ecommerce, the participants seem to be certain about the level of support provided by the government as necessary for successful implementation, which is reflected in the vast majority of policies and regulations that are endorsed by different parts of the government. Therefore, it appears that government initiatives play a major role in e-commerce success with the potential to positively encourage ecommerce development or, more negatively, become a barrier. This was also confirmed by answer 5 (A5), where the government was identified as taking the first step towards encouraging the retailers to move towards e- commerce.

Raising awareness (A4) was also identified as one factor with a major impact on implementation. Awareness in e-commerce refers to the retailers' and customers' perception and comprehension of the benefits of e-commerce [26]. Therefore, a joint collaborative effort is needed to increase knowledge and illustrate the advantages of implementing ecommerce for both customers and businesses. A very interesting statement mentioned by one of the retailers indicated the willingness to learn and the enthusiasm to be involved in e-commerce: 'Like other businesses in the world, we deserve to be part of the online market. We are fully prepared, but we need to know how to start and how to notify people that we are online'. Nevertheless, the coordination and intention to achieve this aspect are a shared responsibility between the private and public sectors, but little has been done in this respect.

Question 5: What Are the Requirements? This question was designed to investigate the retailers' perception of what should be done in order to become an online business provider. Even though some of the answers were provided in previous themes, the answers to this question have emerged by combing previous themes, and the retailers seemed to be interested in summarising the exact requirements to become an online retailer successfully. This may open the door to other retailers to adopt e-commerce. The participants shared the view that establishing active workshops and seminars for traditional retailers on how to conduct their businesses online was foremost at this stage of adoption. Therefore, this should be pursued not only for potential e-commerce retailers but also for all traditional retailers.

Table 8a. Question 5: What are the requirements?

\begin{tabular}{|c|c|l|}
\hline $\begin{array}{l}\text { Question } \\
\text { No. }\end{array}$ & $\begin{array}{l}\text { Answer } \\
\text { No. }\end{array}$ & \multicolumn{1}{|c|}{ Answer } \\
\hline 5 & 1 & $\begin{array}{l}\text { Better workshops and seminars } \\
\text { on how to conduct business } \\
\text { online }\end{array}$ \\
\hline 5 & 2 & $\begin{array}{l}\text { protection law for customers and } \\
\text { retailers in both traditional } \\
\text { shopping and online shopping }\end{array}$ \\
\hline 5 & 3 & $\begin{array}{l}\text { Taxes and customs duties } \\
\text { facilities }\end{array}$ \\
\hline 5 & 4 & $\begin{array}{l}\text { Establishing international trade } \\
\text { agreements }\end{array}$ \\
\hline 5 & 5 & $\begin{array}{l}\text { Increase the level of government } \\
\text { support }\end{array}$ \\
\hline
\end{tabular}


Table $8 \mathrm{~b}$. What are the requirements?

\begin{tabular}{|c|c|c|c|c|c|c|}
\hline Theme 5 & \multicolumn{5}{|c|}{ What are the requirements? } \\
\hline Q5 & M\&T & F & B & G & C & M\&C \\
\hline A1 & $\mathrm{x}$ & $\mathrm{x}$ & $\mathrm{x}$ & $\mathrm{x}$ & $\mathrm{x}$ & $\mathrm{x}$ \\
\hline $\mathrm{A} 2$ & $\mathrm{x}$ & & $\mathrm{x}$ & & $\mathrm{x}$ & \\
\hline A3 & $\mathrm{x}$ & & $\mathrm{x}$ & & $\mathrm{x}$ & \\
\hline A4 & $\mathrm{x}$ & & $\mathrm{x}$ & & $\mathrm{x}$ & \\
\hline A5 & $\mathrm{x}$ & $\mathrm{x}$ & $\mathrm{x}$ & $\mathrm{x}$ & $\mathrm{x}$ & $\mathrm{x}$ \\
\hline
\end{tabular}

Various parts of the public sector were mentioned in this theme, such as no law protecting retailers and customers in general where the participants seemed to be more concerned about their protection. It is worth mentioning that Jordan has not finalised or endorsed a protection law for customers. Consequently, the need for this law is necessary not only for the future of e-commerce transactions in Jordan but also in the traditional environment. The participants also highlighted taxation and customs duties. Currently, all goods and services including online goods are taxed under the normal income tax law, and customs duties also apply for goods in Jordan. This practice may not encourage businesses to use e-commerce. Unlike other countries such as Canada, in 1999 the World Trade Organisation (WTO) ministries agreed to impose no new duties on e-commerce [1]. Therefore, establishing international trade agreements (A4) will provide some benefits which include taxing and customs facilities.

\section{Discussion}

This paper sought to explore retailers' perceptions of adoption and implementation of e-commerce in Jordan. Five areas emerged as major themes in the focus group: a common understanding of the definition of e-commerce, barriers and drivers from retailers' point of view, the readiness and willingness for implementation and adoption, and potential solutions to achieve the transformation from traditional to online businesses. This section also focuses on highlighting the necessary actions of implementing e-commerce in Jordan, as perceived by senior businessmen with traditional businesses and proposing further research to shed light on how to adopt e-commerce successfully.

This paper has identified and described the following themes:

1. A common understanding of e-commerce

2. Collaboration between stakeholders and government

3. Protection law for retailers and customers

4. Taxation and customs duty
5. Raising awareness about e-commerce

6 . The level of support provided by the government

The above- mentioned themes were identified and discussed in a focus group.

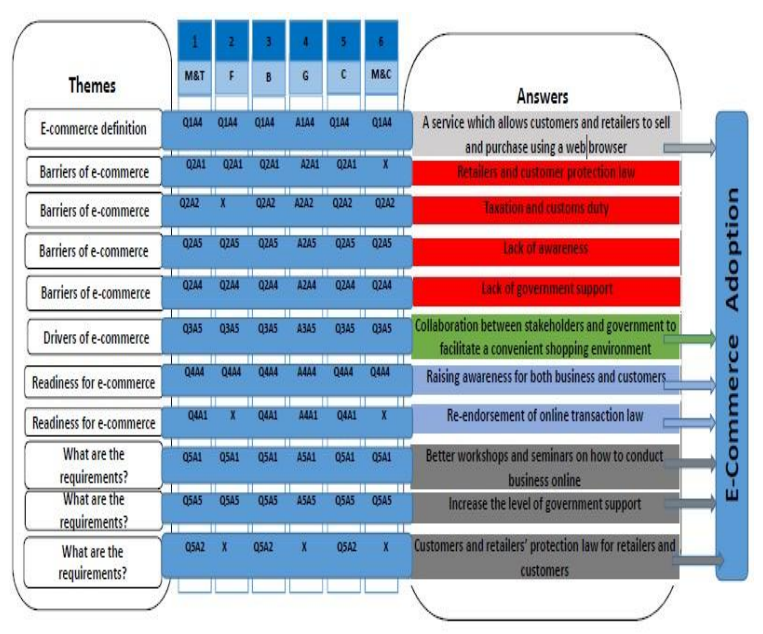

Figure 1. Summary of Findings of E-commerce Adoption

The findings in Figure 1 indicate five different potential areas of contribution and highlight unexplored areas for further research:

1. A common interpretation of what e-commerce means, and how this concept and philosophy were viewed by other retailers emerged in the focus groups. A common understanding of e- commerce among different traditional retailers in Jordan is a good sign. E-commerce was perceived as a transformation phase from a traditional to an online environment to sell and purchase products/services all over the world using the Internet.

2. By adopting e-commerce, retailers thought this would help build a convenient online business environment with an increasing number of potential online retailers in Jordan. As a consequence of technology development, and the need for market expansion, most traditional retailers in Jordan felt ecommerce was an excellent opportunity and they wanted to be part of it.

3. Most of the retailers agreed on the role of government in removing barriers and promoting more e-commerce adoption. The UK is a case in point where there have been consumer protection laws since before e-commerce, and these have been strengthened since e-commerce became prolific. This raises the question: to what extent are the different parts of the government willing to take the initiative forward?

4. All the participants agreed on their need to have enough knowledge about how to conduct their businesses online. Could the collaboration between retailers, government, and stakeholders achieve this? 
If not, should universities or colleges take the initiative and run short courses on practical skills for web-businesses?

5. The impact of the social settings and the environment where the focus group was conducted should be taken into consideration when evaluating these results. A considerable difference in the opinions and views towards e-commerce were noticed, which improve the level of validation of the collected data, as the validity of the opinion may vary from one location to another and from a social setting to another.

\section{Conclusions and Future Research}

E-commerce has become a common and familiar face of business in developed countries. It is, however, regarded as an innovation in many countries with less development, where it is still in its early stage. Most countries including the underdeveloped have quickly adopted the use of internet in various circles of society. In spite of this, e-commerce remains a challenge due to a number of factors, many of which are external and concern international trade like shipping and freight handling.

In this paper, the implementation of e-commerce was investigated from the traditional retailers' perspective. Government support and raising awareness were highlighted as the most common concerns. The study aimed at answering questions related to e-commerce implementation and adoption in Jordan. The barriers were not seen as insurmountable, but the researcher felt that the traditional retailers were still waiting for e-commerce to find them, rather than being proactive about adopting it. This may be partly due to the fact that a great deal of business to consumer (b2c) commerce is still conducted using cash, and the consumers examine the goods personally before they buy them.

The enthusiasm of the participants regarding the transformation was noted in the paper. However, there are still issues requiring a collaborative effort between different parts of the government, stakeholders, and the retailers themselves. This collaboration should aim at developing a strategic plan to create a convenient online environment to ensure successful e-commerce adoption.

It is imperative to adopt an incremental approach to implement e-commerce and implementation should start by utilising the current drivers to remove the main challenges to achieve success. Furthermore, the adoption of e-commerce should be further investigated in order to identify the views of the existing online retailers and understand not only their successful business model but also their perception of successful implementation. The future of ecommerce is not only a technological change introducing new technologies into business but also about changing the relationship and roles between businesses and customers and creating new values. Trust in a non-face to face model is more difficult to establish, and when there are few laws to protect the consumer or the business, in the event of something going wrong, the establishment of trust becomes a priority.

This paper presents the Jordanian traditional retailers' understanding, views, and opinions about e-commerce adoption. This paper contributes to the academic debate by underlining the challenges and opportunities when adopting e-commerce and sheds light on whether it is possible to achieve e-commerce adoption and implementation. Awareness is needed as a first step to develop the required knowledge and understanding; developing workshops and seminars should be a priority. Improved communication between the government and stakeholders is needed to facilitate moving to an online environment. Endorsement of businesses and protection laws for customers are required to create trust and confidence. Regulations and policies need to be examined to encourage more businesses. In addition, collaboration with other players in e-commerce is necessary to enhance accuracy, in particular, collaborating with the Ministry of Communication and Technology (MOICT).

\section{References}

[1] F. Damanpour and J. Madison, "E-business e-commerce evolution: perspective and strategy", Managerial Finance, vol. 27, no. 7, pp. 16-33, 2001.

[2] S. Moodley and M. Morris, "Does e-commerce fulfil its promise for developing country (South African) garment export producers?", Oxford Development Studies, vol. 32, no. 2, pp. 155-178, 2004.

[3] J. Humphrey, R. Mansell, D. Paré and H. Schmitz, "Reality of e-commerce with developing countries", London School of Economics, 2003.

[4] National e-commerce strategy, "National e- commerce strategy, policies and strategies directorate". Ministry of information and communications technology (MOICT). 2013.

[5] R. Abu-Shamaa and E. Abu-Shanab, "Factors influencing the intention to buy from online stores: An empirical study in Jordan", In Proceedings of the 8th IEEE GCC Conference and Exhibition, Muscat, Oman, pp. 1-6, 2015.

[6] M. Al-Shboul and I. Alsmadi, "Building an eCommerce Infrastructure in Jordan: Challenges and Requirements", International Journal of Interactive Mobile Technologies (iJIM), vol. 4, no. 4, pp. 18-24, 2010.

[7] G. Al-Weshah and K. Al-Zubi, "E-business enablers and barriers: empirical study of SMEs in Jordanian communication sector", Global Journal of Business Research, vol. 6, no. 3, pp. 1-15, 2012. 
[8] M. Al-debei and R. Shannak, "The current state of Ecommerce in Jordan: Applicability and future prospects", In Proceedings of the 5th IBIMA Conference on The Internet \& Information Technology in Modern Organizations., Cairo, pp. 457-489, 2005.

[9] C. Ang, R. Tahar and R. Murat, "An empirical study on electronic commerce diffusion in the Malaysian shipping industry", The Electronic Journal of Information Systems in Developing Countries, vol. 14, no. 1, pp. 1-9, 2003.

[10] B. Chan and S. Al-Hawamdeh, "The development of e-commerce in Singapore: The impact of government initiatives", Business Process Management Journal, vol. 8, no. 3, pp. 278-288, 2002.

[11] J. King, V. Gurbaxani, K. Kraemer, F. McFarlan, K Raman and C. Yap, "Institutional Factors in Information Technology Innovation", Information Systems Research, vol. 5, no. 2, pp. 139-169, 1994.

[12] A. Molla, "Exploring the reality of e-commerce benefits among businesses in a developing country", Working Paper No. 22, Informatics, Institute for Development Policy and Management, University of Manchester, 2005.

[13] R. Montealegre, "A Temporal Model of Institutional Interventions for Information Technology Adoption in Less-Developed Countries", Journal of Management Information Systems, vol. 16, no. 1, pp. 207-232, 1999.

[14] P. Tigre and J. Dedrick, "E-commerce in Brazil: Local Adaptation of a Global Technology", Electronic Markets, vol. 14, no. 1, pp. 36-47, 2004.

[15] A. Molla and P. Licker, "eCommerce adoption in developing countries: a model and instrument", Information \& Management, vol. 42, no. 6, pp. 877$899,2005$.

[16] R. AlGhamdi, S. Drew and W. Al-Ghaith, "Factors influencing e-commerce adoption by retailers in SaudiArabia: A qualitative analysis", The Electronic Journal of Information Systems in Developing Countries, vol. 47, 2011.

[17] N. Qirim, "The role of the government and ECommerce adoption in small businesses in New Zealand", International Journal of Internet and Enterprise Management, vol. 4, no. 4, pp. 293-313, 2006.

[18] S. Kurnia, "E-commerce adoption in developing countries: an Indonesian study", The University of Melbourne, 111, 2006

[19] S. Nasco, E. Toledo and P. Mykytyn, "Predicting electronic commerce adoption in Chilean SMEs", Journal of Business Research, vol. 61, no. 6, pp. 697-705, 2008.

[20] A. Papazafeiropoulou, "Inter-Country Analysis of Electronic Commerce Adoption in South Eastern Europe: Policy Recommendations for the Region", Journal of Global Information Technology Management, vol. 7, no. 2, pp. 54-69, 2004
[21] A. H. Zaied, "Barriers to E-Commerce Adoption in Egyptian SMEs", International Journal of Information Engineering and Electronic Business, vol. 4, no. 3, pp. 918, 2012.

[22] A. Scupola, "The Adoption of Internet Commerce by SMEs in the South of Italy: An Environmental, Technological and Organizational Perspective", Journal of Global Information Technology Management, vol. 6, no. 1, pp. 52-71, 2003.

[23] A. Khalfan and A. Alshawaf, "Adoption and Implementation Problems of E-Banking: A Study of the Managerial Perspective of the Banking Industry in Oman", Journal of Global Information Technology Management, vol. 7, no. 1, pp. 47-64, 2004.

[24] R. AlGhamdi, S. Drew and S. Alkhalaf, "Government initiatives: The missing key for e- commerce growth in KSA", In International Conference on e-Commerce, eBusiness and e- Service, Paris, France., vol. 77, no. 3, pp. 0772-775, 2012

[25] M. Halaweh and C. Fidler, "Security perception in ecommerce: Conflict between customer and organizational perspectives", In Computer Science and Information Technology, IMCSIT 2008. International Multiconference on IEEE, pp. 443- 449, 2008.

[26] E. Rogers, Diffusion of innovations. New York, 1995.

[27] S. Al-Hudhaif and A. Alkubeyyer, "E- Commerce Adoption Factors in Saudi Arabia", International Journal of Business and Management, vol. 6, no. 9, p. 122, 2011.

[28] S. Al-Somali, R. Gholami and B. Clegg, "An investigation into the acceptance of online banking in Saudi Arabia", Technovation, vol. 29, no. 2, pp. 130-141, 2009.

[29] S. Sait, K. Al-Tawil and S. Hussain, "E- Commerce in Saudi Arabia: adoption and perspectives", Australasian Journal of Information Systems, vol. 12, no. 1, pp. 54-74, 2004.

[30] M. Tarafdar and S. Vaidya, "Challenges in the adoption of E-Commerce technologies in India: The role of organizational factors", International Journal of Information Management, vol. 26, no. 6, pp. 428-441, 2006.

[31] S. Vaithianathan, "A review of e-commerce literature on India and research agenda for the future", Electronic Commerce Research, vol. 10, no. 1, pp. 83-97, 2010

[32] E. Al Nagi and M. Hamdan, "Computerization and eGovernment implementation in Jordan: Challenges, obstacles and successes", Government Information Quarterly, vol. 26, no. 4, pp. 577-583, 2009.

[33] H. Yaseen, K. Dingley and C. Adams, "Capturing the growth of e-commerce in Jordan using a novel research approach", International Journal of Management and Commerce Innovations, vol. 3, no. 2, pp. 811-827, 2016. 
[34] N. Kshetri, "Barriers to e-commerce and competitive business models in developing countries: A case study", Electronic Commerce Research and Applications, vol. 6, no. 4, pp. 443-452, 2008.

[35] M. Kapurubandara and R. Lawson, "SMEs in developing countries need support to address the challenges of adopting e-commerce technologies", In BLED 2007 Proceedings, p. 24, 2007.

[36] M. Al-Debei and E. Al-Lozi, "Implementations of ICT innovations: A comparative analysis in terms of challenges between developed and developing countries", International Journal of Information, Business and Management, vol. 4, no. 1, pp. 224-252, 2012.

[37] R. AlGhamdi, J. Nguyen, A. Nguyen and S. Drew, "Factors influencing e-commerce adoption by retailers in Saudi Arabia: A quantitative analysis", International Journal of Electronic Commerce Studies, vol. 3, no. 1, p. 83, 2011.

[38] A. Efendioglu and V. Yip, "Chinese culture and ecommerce: an exploratory study", Interacting with Computers, vol. 16, no. 1, pp. 45-62, 2004.

[39] I. Elbeltagi, "E-commerce and globalization: an exploratory study of Egypt", Cross Cultural Management: An International Journal, vol. 14, no. 3, pp. 196-201, 2007.

[40] M. Al-Ibraheem and H. Tahat, "Regulating Electronic Contracting in Jordan", In 21st BILETA Conference, Malta, pp. 6-19, 2006.

[41] A. Al Bakri, "An Overview of Information and Communication Technology (ICT) in Jordan: Review the Literature of Usage, Benefits and Barriers", International Journal of Internet and Distributed Systems, vol. 01, no. 02, pp. 9-15, 2013.

[42] M. Eid, "Customer satisfaction, brand trust and variety seeking as determinants of brand loyalty", Customer satisfaction, brand trust and variety seeking as determinants of brand loyalty, vol. 12, no. 1, p. 78, 2011.

[43] M. Gommans, K. Krishnan and K. Scheffold, "From brand loyalty to e-loyalty: A conceptual framework", Journal of Economic and Social Research, vol. 3, no. 1, pp. 43-58, 2001.

[44] N. Kassim and N. Asiah Abdullah, "The effect of perceived service quality dimensions on customer satisfaction, trust, and loyalty in e-commerce settings: A cross cultural analysis", Asia Pacific Journal of Marketing and Logistics, vol. 22, no. 3, pp. 351-371, 2010.

[45] F. Reichheld, R. Markey Jr and C. Hopton, "Ecustomer loyalty-applying the traditional rules of business for online success", European Business Journal, vol. 12, no. 4, p. 173, 2011.

[46] H. Yaseen, M. Alhusban, K. Dingley, and A. Alhosban, "Facilitating E-Commerce in Jordan: A Qualitative Analysis", International Journal of Digital Society (IJDS), vol. 7, issue. 4, pp. 1206-1213, 2016.
[47] A. Scupola, "SMEs' e-commerce adoption: perspectives from Denmark and Australia", Journal of Enterprise Information Management, vol. 22, no. 12, pp. 152-166, 2009.

[48] H. Yaseen, K. Dingley and C. Adams, "The government's role in raising awareness towards ecommerce adoption: The case of Jordan", In Proceedings of the 15th European Conference on eGovernment, ECEG 2015, Academic Conferences Limited., p. 316, 2015.

[49] M. Kapurubandara and R. Lawson, "Barriers to Adopting ICT and e-commerce with SMEs in developing countries: an Exploratory study in Sri Lanka", CollECTeR. Adelaide, 2006.

[50] H. Yaseen, K. Dingley and C. Adams, " An Empirical Study of Factors Influencing E-Commerce Customers' Awareness in Jordan", In Information Society (i-Society), 2016 International Conference on, pp. 63-67. IEEE, 2016. 